\title{
Athletes vs. bloggers: influence on purchase preferences of the Generation Z
}

\author{
Josef Voráček*, Martina Bernardová
}

Faculty of Physical Education and Sport, Charles University, Prague, Czech Republic

* Corresponding author: voracek@ftvs.cuni.cz

\begin{abstract}
The paper deals with the comparison of the impact of the use of athletes and bloggers in marketing communication on purchasing preferences of individuals which belong to the so-called Generation Z. There are two interdependent methods used for the research. The first of these methods is a questionnaire survey, which includes 508 respondents. 32 respondents separated in two groups attended the second method, which is a focus group. The research results show that athletes influence the behavioral intentions of members of the Generation Z more than bloggers in every researched sphere. The main difference in effectivity is clear from the comparison between both groups by respondents.
\end{abstract}

\section{KEYWORDS}

marketing communication; shopping behaviour; reference group; Generation Z; sports celebrity; influencer

D0I

10.14712/23366052.2021.7

(C) 2021 The Authors. This is an open-access article distributed under the terms of the Creative Commons Attribution License (http://creativecommons.org/licenses/by/4.0), which permits unrestricted use, distribution, and reproduction in any medium, provided the original author and source are credited. 


\section{INTRODUCTION AND THEORETICAL BACKGROUND}

Knowing the customer is one of the cornerstones of an organisation's success. Nowadays, it is essential for firms to know what target groups to aim at, and what their characteristics and shopping preferences are. To a certain degree, knowing the customer allows brands to work on influencing the shopping preferences of the customer. One way to do that is to enter into cooperation with a famous person capable of attracting the attention of the customer and exerting a tactical influence over the customer's decision-making. An interesting group that firms often cooperate with is sports celebrities. Nowadays, they no longer promote sports goods only; they also appear in advertisements for companies producing, for instance, cars, clothes, electronics or cosmetics.

Numerous studies have been carried out on the influence sports celebrities exert over the shopping preferences of various age groups in the last years - especially the young, promising generation (Sassenberg, 2015; Sassenberg et al., 2018; Düsenberg, de Almeida, de Amorim, 2016; Hameed, Madhavan, 2017; Liu et al., 2016; Dugalić, Lazarević, 2017). Some studies carried out by international authors are also worth mentioning: Bush, Martin, Bush (2004), Dix, Phau, Pougnet (2010), Shuart (2007), Koernig, Boyd (2009), Simmers, Damron-Martinez, Haytko (2009), Baig, Siddiqui (2012).

Nevertheless, a direct comparison with a different referential group could offer an interesting perspective on the influence of sports celebrities on shopping preferences. That is the reason why this research compares the influence of sports celebrities and bloggers - two significant referential groups of the adolescent generation.

Casaló, Flavián, Ibáñez-Sánchez (2018) claim that influencers, e.g. among bloggers, can be considered opinion-leaders. The study conducted by Uzunoglu, Kip (2014) uses the term "digital opinion-leader". It is social networks that transform the perception of opinion-leaders able to exert a faster, space- and time-unlimited influence over others, says Jungnickel (2018). The content is not only created by media houses, but also by firms, organisations and even individuals who strive to inform the public and participate in forming the public's attitudes.

\section{Celebrity Endorsement}

Celebrity Endorsement is defined as a kind of an advertisement campaign featuring a famous person using their fame to promote a product or a service (Lee, 2016). Dacko (2008) claims that the term "Celebrity Endorsement" has now become more wide-spread than the formerly superior term "Celebrity Marketing". At the moment, it is a term covering all activities performed by celebrities in marketing communications.

Khatri (2006) says that within Celebrity Endorsement, famous people make use of their name and fame in order to promote a product and a service in an area that does or does not fall within the field of their expertise. Smith (2008) also mentions the possibility of making use of a celebrity to improve the company's image: "Marketing support appears at the moment when a well-known celebrity and/or an athlete makes use of their fame in order to help a company sell its products. They can also make use of their name to improve the image of the company, its products or brand." In today's colourful 
marketing, the brand's and the company's image is one of the important aspects for catching the attention of the young generation consumers, says Voracek (2015).

Based on the focus of a given research, the theoretical background of Celebrity Endorsement relates in particular to sports celebrities that are popular among the public, that the public often associates with, that the members of the public often support as their fans and identify with them in certain aspects (Kahle, Riley, 2004). Athletes, unlike other celebrities, do not only depend on their media representation, but also on their sports results (Stevens, Lathrop, Bradish, 2003). Athletes deserve to be admired in particular thanks to their athletic skills and the success achieved (Liu et al., 2016; Dugalić, Lazarević, 2017). Publicly-known celebrities attract media coverage which presents them to the wide public (SSassenberg et al., 2018).

\section{Influencer Marketing}

A similar form of marketing communication is a cooperation with influencers able to reach hundreds of thousands of individuals on social networks (Dhanesh, Duthler, 2019; Kapitan, Silvera, 2016). Just as the development of modern technologies, the internet and the access thereto is accelerating, so is marketing - especially its digital part (Silva et al., 2020). Over the past years, the on-line environment has been offering interesting trends in reaching out to the customer, either through PPC ads, SEO, social networks and/or Influencer Marketing (Caslavova, Voracek, 2019).

Influencer Marketing means: "the art and science of influential people participating in the on-line environment who can share information about a brand with their audience by means of sponsored content" (Sammis, Lincoln, Pomponi, 2016, p. 7). It is an entire strategy based on the use of an influencer and their influence over their followers with the aim of promotion and an increase in sales (Baker, 2017). Similarly to Celebrity Endorsement, Influencer Marketing is based on the fame of a given person and their influence over their fans (Kapitan, Silvera, 2016). The Forbes magazine has even labelled influencers as the modern celebrity endorsement and regards their work as building one's own brand (Weinswig, 2016; Voracek, 2019). Influencer Marketing is essentially specific in that it is about the relationship between the influencer and the follower based on their similar interests, opinions and trust (Torres, Augusto, Matos, 2019). Novotny (2017, p. 41) specifically pinpoints trust in the relationship, as Influencer Marketing: "represents a unique and honest relationship between consumers, brands and influencers". Thanks to the trust between the influencer and the consumer, Influencer Marketing is a unique and modern tool to reach goals such as brand building, increasing the awareness about a product or gaining new followers on social networks (Torres, Augusto, Matos, 2019). Consumers trust recommendations made by their family and friends (Chuang, Cheng, Hsu, 2012). Sammis, Lincoln, Pomponi (2016) claim that thanks to the influencer's personal attitude, followers view influencers as friends.

Social networks have brought the word-of-mouth practise back to life and thanks to on-line influencers; it can be used on an enormous scale (Scott, 2015; Waller, 2016). In order for the brands to target their potential consumers well, they must first target opinion-leaders well (Kapitan, Silvera, 2016). It is them who become the intermediaries between the brand and the consumer and them who share their experiences and opinions (Cramer, 2017). Prikrylova, Jahodova (2010) also perceive Influencer 
Marketing as identifying and influencing opinion-leaders with the ability to influence the opinions of others. It is the adolescents in particular who describe their favourite youtubers as being similar to themselves, sharing the same interests, being honest and giving good advice (Torres, Augusto, Matos, 2019).

Abidin (2016) says influencers are "micro-celebrities" who gain their followers on blogs and social networks, and create content with the help of textual and visual story-telling featuring personal stories. The term "influencer" used to be primarily used for bloggers or vloggers (De Veirman, Hudders, Nelson, 2019). At the moment, influencers are active on various platforms such as Facebook, Youtube, Instagram, TikTok and Twitter (De Veirman, Hudders, Nelson, 2019). They either use one of the platforms or combine more of them (De Veirman, Hudders, Nelson, 2019). In his article, Pophal (2016) highlights the vast applicability of the term "influencer" - it is not only famous bloggers and celebrities who can be one. Anyone adding content to social media and influencing followers, be it only a small circle, can be an influencer (De Veirman, Hudders, Nelson, 2019; Pophal, 2016; Abidin, 2016). For the purpose of this research, the term "blogger" is synonymous to the term "influencer", the primary activity of whom is to create content on social media and/or blogs.

There are various categories of influencers based on their interests, for instance: lifestyle, fashion, travelling, fitness and sport, beauty, art, games, education and many more (Levine, 2017). To strike up cooperation with a mega-influencer means not only securing an advertisement for the company, but also gaining a certain prestige and potential to significantly increase sales (Davis, 2019).

The consumers themselves choose what, where, and when they want to follow (Debroff, 2016). Voluntary following and seeking information provided by influencers is a strong part of Influencer Marketing (Lou, Yuan, 2019). This is also why Influencer Marketing is the fastest growing tool for gaining new customers in the on-line environment (Odell, Wiley, Talamantez, 2016). It can lead to consumer participation up to 16 times higher than with the traditional forms of paid media (Odell, Wiley, Talamantez, 2016).

If the potential of Influencer Marketing is well-harnessed, it can function as a cost-effective marketing type that can be a source of creative content with the possibility to reach specific target groups in a natural way (Waller, 2016).

For the purposes of this research, anyone with an influence exerted over other individuals and with an active presence on social media can be an influencer.

\section{Generation Z}

Similarly to the case of other generations, the experts, too, do not exactly agree on the birth years of individuals belonging to Generation Z. For McCrindle (2014), Generation $\mathrm{Z}$ comprises young people born between the years 1995-2009. Fry, Parker (2018) expand Generation Z by including individuals born between 1997 and 2012, that is people aged 8 to 23 in 2020. Nevertheless, they (Fry, Parker, 2018) immediately add that the 16-year-long range may change in the future, depending on the changes within the generation and its crystallisation. There is something more important than an exact definition of birth years - values, social behaviour and attitudes characteristic for Generation Z, which shall serve as a basis for further stabilisation of the time range (McCrindle, 2014; Fry, Parker, 2018; Seemiller, Grace, 2016). 
One of the most significant factors influencing Generation $\mathrm{Z}$ is, no doubt, modern technology and access thereto (Seemiller, Grace, 2016). Post-Millennials, a name also used for Generation $\mathrm{Z}$, were born into a digitalised world offering them more open access to various modern technologies from a very young age (Seemiller, Grace, 2016). It is the first generation that has not experienced the times without mobile devices or the internet (Bergh, Behrer, De Maeseneire, 2016). Modern technology is a common part of their every-day life (Bergh, Behrer, De Maeseneire, 2016). The way they perceive modern technology, the presence of which they take for granted, has earned them the name "digital natives" (Koulopoulos, Keldsen, 2016). According to Stillman, Stillman (2017), another specific aspect regarding modern technologies is the fact that the young generation perceives even physical aspects - e.g. places and people - in a digital sense.

Some literary sources offer the name "iGen" for the generation examined, with the name comprising, on the one hand, the pronoun "I", reflecting the self-centeredness of the individuals, and, on the other hand, referring to the internet and to the Apple smart phone owned by as many as two out of every three American teenagers (Rosen, 2010; Twenge, 2017).

Generation $\mathrm{Z}$ members tend to have older parents, which means better financial and property stability for them. In this case, the parents often belong to the $\mathrm{X}$ or $\mathrm{Y}$ Generations and raise their offspring to be individualistic; they support them and remind them to have a realistic view of the world and to find their own ways (Sladek, Grabinger, 2018). Even though Generation $\mathrm{Z}$ is still only coming of age, the research of Sladek, Grabinger (2018) shows that, for now, they are well financially-educated. The majority of young people find the time to search for reviews on products and consequently to search the internet to find the best and the most cost-effective option (Sladek, Grabinger, 2018). The young people can search for reviews on websites designated for this purpose, on on-line store websites, but also on social media where they can be exposed to the influence of their friends and their favourite influencers (Sladek, Grabinger, 2018).

\section{RESEARCH OBJECTIVE}

The main research objective is, with the use of a marketing research, to compare the levels of influence of athletes and bloggers exerted over the shopping preferences of the members of the so-called Generation $\mathrm{Z}$.

\section{METHODOLOGY}

The research makes use of both quantitative and qualitative methods. The quantitative part is designed to bring results with measurable data. The quantitative data shall also serve to generalise the results of the research. The second part of the research supplements the data by a qualitative perspective intended to discover the causes of the present state. The research connects both types of the research for the purpose of an overall assessment of the issue examined.

A questionnaire survey has been chosen for the purpose of the quantitative method of the research. The basic tool thereof is a questionnaire containing a statement with 
the respondents rating the level of agreement thereon by using a 5-point Likert scale ( 1 - strongly disagree, 5 - strongly agree). Furthermore, the questionnaire contains three open questions regarding cooperation with bloggers and athletes.

The construction of the whole questionnaire divides the items of the issue examined into 5 dimensions. Specifically, it relates to the purchase intention, to the positive word-of-mouth, or else a positive verbal communication, to the brand loyalty (Bush, Martin, Bush, 2004), to the harmony and trustworthiness, and finally to the area of comparison, where the respondents have three statements where they choose the side of the athlete or the influencer. The individual items of the questionnaire are provided in Appendix 1.

The questionnaire has been made in two modifications, one is focused on statements and questions regarding sports celebrities, the other is focused on bloggers. The individual questions and statements are the same, only the subject of the focus thereof is either an athlete or an influencer.

508 respondents took part in the questionnaire survey. For the purpose of ease of reference, in regard to the two modifications of the questionnaire, Table 1 has been created to display the number of respondents in view of the modification of the questionnaire and of the gender. The first version of the questionnaire is focused on questions and statements regarding the influence of athletes (in the Table and hereinafter referred to as the "ATHLETE"); the second version, on the other hand, is focused on the influence of bloggers (in the Table and hereinafter referred to as the "BLOGGER”).

Table 1 Respondent Structure

\begin{tabular}{lcccc}
\hline & \multicolumn{2}{c}{ ATHLETE } & \multicolumn{2}{c}{ BLOGGER } \\
\hline \multicolumn{1}{c}{ Variants } & Absolute size & Relative size (\%) & Absolute size & Relative size (\%) \\
\hline Male & 147 & 57.87 & 152 & 59.84 \\
Female & 107 & 42.13 & 102 & 40.16 \\
Total & 254 & 100 & 254 & 100 \\
\hline
\end{tabular}

The number of respondents in both modifications of the questionnaire was 254; the total number was, therefore, 508 respondents. Men represented a bigger proportion of the respondents, nevertheless their number did not exceed $60 \%$.

The second research method was a focus group. The order of the methods has been selected purposefully so that the discussion follows the questionnaire survey and the data collected therein. The first group comprised 18 respondents ( 15 women and 3 men); the second group comprised of 14 male respondents. The total number of participants of the focus group was 32 respondents - 15 women and 17 men. 


\section{RESULTS}

Specific results of the influence of athletes and influencers on the shopping preferences are divided into chapters corresponding to the individual dimensions of the questionnaire.

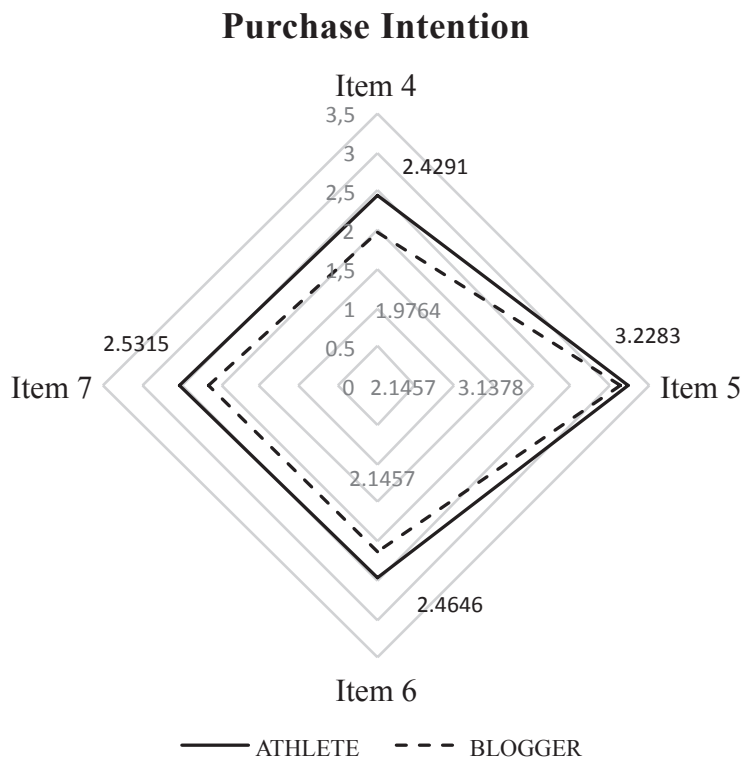

Figure 1 Mean values of the area of the Purchase Intention

\section{Purchase Intention}

The respondents agreed with the statements more when the subject was an athlete (see Figure 1). It can be stated that the respondents' purchase intention is higher if the brand and/or the product is connected to the name of an athlete rather than a blogger.

Unlike in the case of the questionnaire survey, the group discussion respondents (focus groups) were more open to purchasing products on the basis of recommendations made by bloggers. A few of the participants of both of the discussion groups admitted purchasing a product thanks to an advertisement seen presented by influencers. The Generation $\mathrm{Z}$ chapter states that the individual tends to think their purchase through and to make rational decisions, as is apparent from this contribution to the discussion: "I do not simply buy something just because I saw it being praised on Instagram. I like to find out some information about the product beforehand, its pros and cons" (a man, discussion group No. 1). The respondents share a similarly rational view of cooperation with athletes.

\section{Positive Word-of-Mouth}

With regard to the research sample of individuals, the whole area of positive verbal communication has proven higher effectiveness of using athletes within marketing communications (see Figure 2). The respondents lean more towards the effective- 
ness of a product promoted by an athlete rather than a blogger. In a similar fashion, they also notice that the popularity of the celebrity is transferred onto the product. In a more varying degree, they take more pleasure in purchasing a product promoted by an athlete rather than a blogger. The results of the Word-of-Mouth dimension depict the fact that the respondents have a higher tendency to give more positive feedback on a cooperation of brands with athletes rather than bloggers which is most visible in Figure 2 at the mean values of the item No. 11 .

\section{Positive Word-of-mouth}

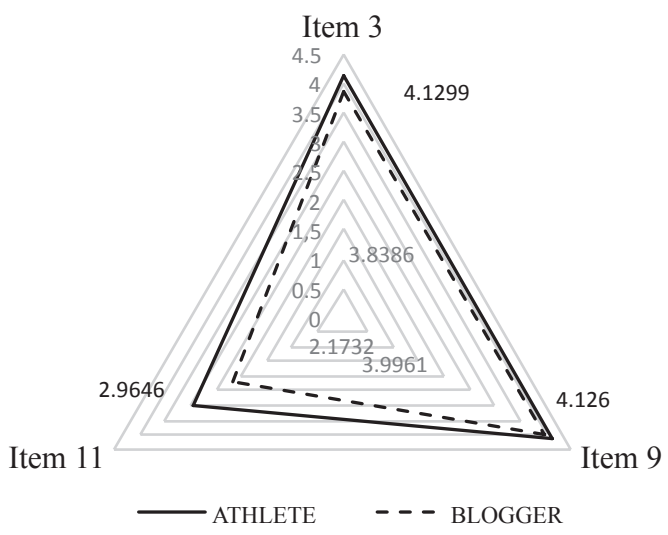

Figure 2 Mean values in the Positive Word-of-Mouth area

The comments in the discussion groups supported the results of measuring the item regarding the negative impact of the blogger's image on the product. The respondents also stated that they discuss some videos with friends and that they themselves, for instance, review products that are the subject of the videos. The participants are of the opinion that in the case of the athlete's influence, their sports results play an important role.

\section{Brand Loyalty}

The items within the Brand Loyalty dimension showed a significantly higher influence of neither the athletes nor the bloggers on the shopping preferences of the respondents. The athletes show a slightly higher influence on the shopping preferences of the individuals examined.

The area of Brand Loyalty is also connected to the ability to recall a brand using Celebrity Endorsement and/or Influencer Marketing. Based on the results of item No. 14, it can be assumed that the consumers in the age group examined tend more to recall a brand that is connected to an athlete rather than a blogger. On the other hand, however, the respondents mentioned more names of brands in connection to influencers, as depicted in Figures 3 and 4. The brands mentioned most often in both of the modifications belong among sports brands. The absolutely most often appearing brand was the sports brand Nike with 53 mentions in the ATHLETE modification and 9 in the BLOGGER modification. The second most often mentioned brand was the company 
Adidas with 25 mentions in the ATHLETE modification and 12 in the BLOGGER modification. The majority of the brands come from abroad, which refers to their financial capacities and the possibility to enter into cooperation with famous faces.

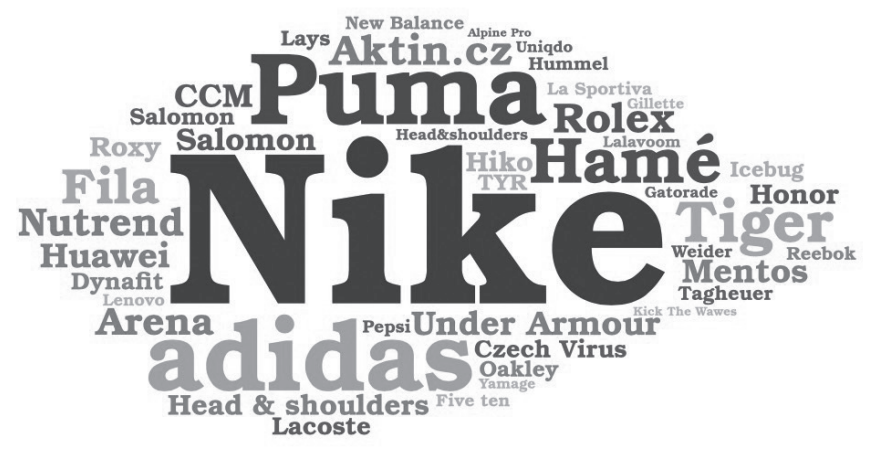

Figure 3 Answers to item No. 14 - ATHLETE

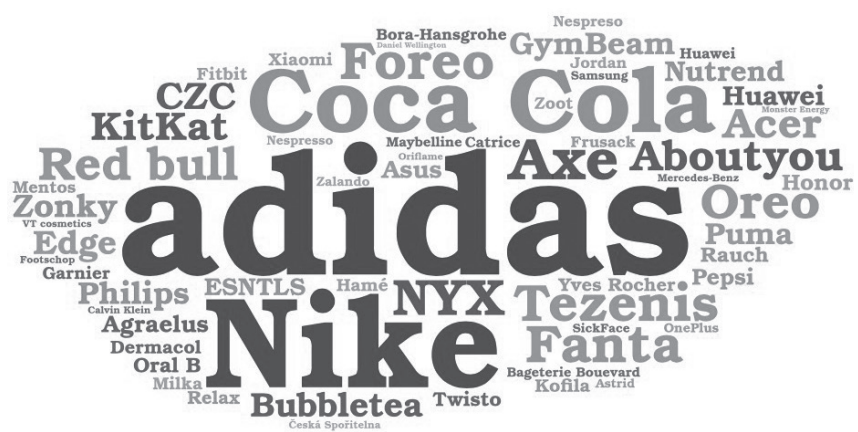

Figure 4 Answers to item No. 14 - BLOGGER

The focus group shows that in some cases the respondents do not tend to purchase a product of the brand promoted, but they start to notice it more. The discussion participants prefer long-term cooperation and negatively perceive one blogger promoting competing brands within a short-term period.

\section{Harmony/Trustworthiness}

The values of three items from the Trustworthiness dimension suggest an important interconnection of a celebrity and a product they promote (see Figure 5). Brands should thus focus on cooperating with celebrities who harmonize with the product, who will actually make use of it and promote it based on their personal experience with it. The name of the celebrity is similarly important as it can influence the consumer to alter their opinion. This area has given rise to the fact that the respondents show a slightly higher degree of trust to advertisements featuring athletes.

Generation $\mathrm{Z}$ individuals, who took part in the discussion groups, were sceptical towards the blogger-brand cooperation. They claim to not let themselves be influ- 


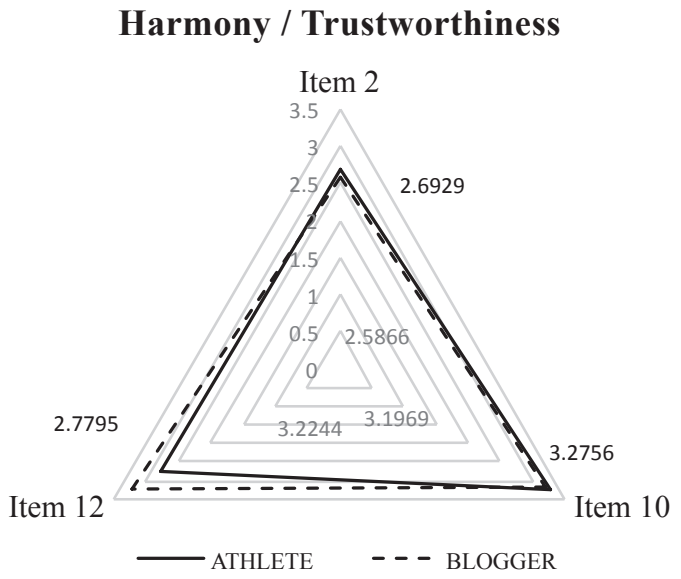

Figure 5 Mean values of the area Harmony/Trustworthiness

enced by Influencer Marketing and to be of the opinion that advertisements are aimed at younger people more. If the respondents cannot see the results of using the product, they do not trust it. They realise that the nature of the cooperation is a paid cooperation and they regard the products as such. On the other hand, the respondents think that athletes truly do use the products promoted and thus the respondents trust them more. This relates to the fact that the participants think that thletes should promote products they understand and that fall within the area of their interest.

\section{Comparison}

The complete Figure 6 of the mean values relating to the dimension of Comparison implies that the respondents trust athletes more, and more likely let themselves be persuaded by athletes. The lower the mean value, the more the respondents inclined to select the answer Athlete. Answers of a similar value in both modifications of the

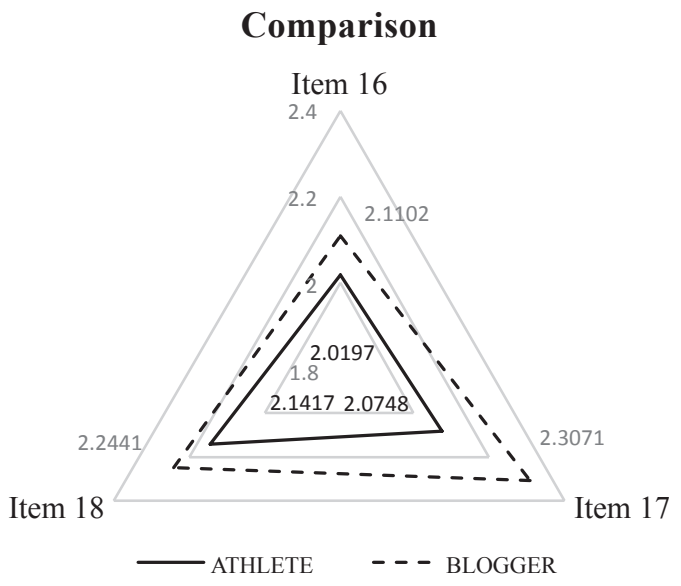

Figure 6 Mean values of the area of Comparison 
questionnaire indicate that the respondents are truly more likely to be persuaded by athletes making the results thus reliable. The results of the measuring perhaps result from the fact that athletes mostly tend to promote sports brands and the consumers can be persuaded that the given products are actually used by the athlete during races and matches. Athletes also do not tend to change the brands they promote and continue to support the brand for more than one season. Bloggers, on the other hand, more often cooperate with various firms, which can mean less transparency for the respondents.

\section{DISCUSSION}

The respondents often have their favourite athletes and bloggers whom they follow on social networks. The focus group participants follow athletes because of the attractiveness of the sports environment, because of the attempt to become better at sports and because they are the athlete's fans. They follow bloggers to be inspired and entertained. For these reasons, it can be inferred that the respondents view athletes as heroes with sports achievements. Therefore, advice provided by athletes can be perceived as more important. Shuart (2007), Stevens, Lathrop, Bradish (2003) say that this perception of athletes underlines their position as heroes. Bloggers rather act as friends, encountering the same problems their followers do, as stated by Sammis, Lincoln, Pomponi (2016). An advantageous fact for bloggers is that the advice given by friends is very valuable for teenagers. Nevertheless, it is up to each athlete and blogger to make use of this disposition to strengthen the trust and their name overall. The results of the questionnaire survey imply that in marketing communications of firms, famous celebrities from the sports environment exert a more effective influence over the respondents than bloggers do. The comparison part of the questionnaire clearly shows a higher trustworthiness of athletes when presenting products. This trend has also been proven in the discussion groups. The respondents are of the opinion that the use of a product can be more likely verified by an athlete rather than an influencer.

The survey participants are more likely to buy a product on the basis of a recommendation made by an athlete rather than a blogger. However, this fact is dependent on specific cases of the athlete's way of use of the product. The majority of the respondents prefer athletes in advertisement campaigns focused on the sports sector, or else nutrition and other areas of the athlete's activity. This relates to the persuasiveness of the advertisement. Bloggers more often present products that they, at the first sight, do not use or which do not fall within the area of their interest - which decreases the persuasiveness of the campaign and the blogger's influence. This relates to the fact stated by Waller (2016), saying that the target group should be reached in the most natural - and persuasive - form possible. Even in the case of persuasiveness, the majority of respondents incline towards athletes.

Approximately one half of the respondents, pursuant to the questionnaire survey, are more likely to be influenced to purchase a product promoted by an athlete and/or an influencer. This corresponds to the fact of how many respondents have already purchased a product on the basis of an advertisement made by an athlete and/or an influencer. However, the respondents definitely see the effectiveness of using famous faces in advertising campaigns and think that they influence the consumer. In this regard, 
the respondents themselves admit to being influenced, as presented in various studies on the previous Generation Y (Bush, Martin, Bush, 2004; Dix, Phau, Pougnet, 2010; Shuart, 2007; Koernig, Boyd, 2009; Simmers, Damron-Martinez, Haytko, 2009; Baig, Siddiqui, 2012; Voracek, Caslavova, 2019). These contradictory statements may imply that the respondents do not want to be in the role in which they can be influenced or controlled by others. Another fact can work in a similar fashion here in that the respondents do not always knowingly recollect the connection between the product purchased and its promotion by an athlete or a blogger. This is confirmed in a study conducted by Voracek, Caslavova (2019). Even though the overall answers do not give the impression of a straight-forward effectiveness in using famous celebrities in advertisements, the results imply a higher effectiveness and a greater influence of athletes. The results acquired can prove greater familiarity with brands in the area of Celebrity Endorsement and that athletes are used more than bloggers. Influencer Marketing is a rather young marketing channel which is developing at a dynamic pace and firms do not yet have much experience with it. Nonetheless, there has been some evident dynamic development (Caslavova, Voracek, 2019; Weinswig, 2016; Voracek, 2019; Dhanesh, Duthler, 2019; Kapitan, Silvera, 2016; Silva et al., 2020; Baker, 2017; etc.).

The bloggers themselves are still learning how to approach the advertising cooperation and it often takes place in the absence of an intermediary who would provide advice to both parties. This especially concerns the micro-influencers, as described by Abidin (2016), as well as Jungnickel (2018). In this case, athletes make use of their managers who have been pursuing the issue examined for a long time and can thus provide suitable recommendations.

It can be stated that the cooperation between brands and famous celebrities provides for a higher awareness of the brand. The respondents remember it better and, when selecting a product, they are likely to include it among the items they consider. To help spread the name of a brand, it is suitable to enter into a cooperation with a face that the target group knows well. It is the fame and image of a brand that Voracek (2015) regards as very important.

The research shows interesting findings which open the doors for further studies of the issue of using athletes and bloggers in marketing communications of firms.

This area would benefit from a discovery of individual areas in which athletes influence the consumer and vice versa. Further research questions could also be concerned with the athletes themselves, e.g. what aspects the respondents view as giving rise to the trustworthiness of the athlete. Various communication channels could be yet another point of interest. Generation $\mathrm{Z}$ makes use of the most various communication channels and some can be more attractive and influential than others.

\section{CONCLUSION}

Although Generation $\mathrm{Z}$ is still being formed, in a few years' time, it will belong among the strongest economic groups. The sample of 508 respondents took part in the questionnaire survey performed and 32 respondents took part in the group discussions within the research conducted. The data collected show the fact that the respondents take notice of commercial messages featuring athletes and bloggers and generally regard them as effective. They even see it as beneficial to have the option of getting 
to know more about a product, to see the product in action and to see it compared with other alternatives. Despite a small proportion of respondents admitting to have bought some product on the basis of an athlete's or a blogger's recommendation, they do not think that they are fundamentally influenced by this kind of advertisement. The contradictory answers in some of the areas most certainly did not overshadow the comparison part of the research, which has presented interesting observations. When young people compare the two groups of famous celebrities, the answers quite clearly agree on athletes being more trustworthy. The trust relates to the persuasiveness that is yet again found more often with athletes rather than with bloggers. The majority of the respondents are more likely to purchase a product which is promoted by their favourite athlete. The results show a higher effectiveness in making use of athletes rather than bloggers in marketing communications.

In order to retain or to increase the effectiveness of athletes and bloggers in commercial messages, it is necessary to, in particular, take account of the harmony between the products and the celebrity. The respondents like to believe a promoter in case that it is obvious that the product is used by them and that they are content with it. It is the use of the product that is one of the factors that make the respondents tend to trust athletes more. By using a product, the celebrity also shows that they understand the product to a certain degree and that they use it for the purpose the product is intended for. This knowledge leads to the celebrity being perceived as someone who can recommend the product. The research is only peripherally concerned with the issue of making use of bloggers and athletes as celebrities promoting products. Despite this fact, the research has proven some statements mentioned in expert literature and, at the same time, it has offered a comparison of two different groups that Generation $\mathrm{Z}$ looks up to.

Athletes are more likely to exert influence over young people. However, it is both athletes and bloggers who can provide for a higher awareness of the brand, for the attractiveness of the brand and for increasing the interest in products. All results depend on the selection of a suitable celebrity and due participation in a specific advertising cooperation.

\section{ACKNOWLEDGEMENTS}

This work was supported by the scientific branch development program PROGRESS [Q19] at the Charles University in Prague.

\section{REFERENCES}

Abidin, C. (2016). Aren't these just young, rich women doing vain things online? Influencer selfies as subversive frivolity. Social Media + Society, 2(2), 1-17.

Baig, F., \& Siddiqui, K. (2012). Impact of sports celebrity endorsements on the purchase intentions of Pakistani youth. Journal of Independent Studies and Research, 10(1), 23-42.

Baker, S. (2017). 9 Of The Biggest Benefits Of Social Influencer Marketing You Need To Know Now. Retrieved from https://shanebarker.com/blog/biggest-benefits-socialinfluencer-marketing/.

Bergh, J. V. D., Behrer, M., \& De Maeseneire, P. (2016). How Cool Brands Stay Hot: Branding to Generation $Y$ and $Z$. London: Kogan Page. 
Bush, A. J., Martin, C. A., \& Bush, V. D. (2004). Sports Celebrity Influence on the Behavioral Intentions of Generation Y. Journal of Advertising Research, 44(1), 108-118.

Casaló, L. V., Flavián, C., \& Ibáñez-Sánchez S. (2018). Influencers on Instagram: Antecedents and consequences of opinion leadership. Journal of Business Research, 115.

Cramer, T. (2017). How to Launch an Influencer Campaign. Retrieved from http:// www.econtentmag.com/Articles/Editorial/Feature/How-to-Launch-an-Influencer -Campaign-116571.htm.

Caslavova, E., \& Voracek, J. (2019). Marketing Trends in Social Networking Sites Usage in Sport. International Journal of Sport Communication, 3(4), 396-400. UT-WOS: 000467818300003.

Chuang, S. C., Cheng, Y. H., \& Hsu, C. T. (2012). The influence of suggestions of reference groups in the compromise effect. Journal of Economic Psychology, 33(3), 554-565.

Dacko, S. G. (2008). The advanced dictionary of marketing: putting theory to use. New York: Oxford University Press.

Davis, M. (2019). The 3 Types of Influencers Explained: Mega, Macro \& Micro. Retrieved from https://www.ifluenz.com/blog/2019/04/16/3-types-influencers-explained-megamacro-micro/.

Debroff, S. (2016). 5 Must-Have Elements for Influencer Marketing Sales Success. Retrieved from https://www.chiefmarketer.com/5-must-have-elements-for-influencermarketing -sales-success/.

De Veirman, M., Hudders, L., \& Nelson, M. R. (2019). What Is Influencer Marketing and How Does It Target Children? A Review and Direction for Future Research. Frontiers in Psychology, 10, Dec., 2685.

Dhanesh, G. S., \& Duthler, G. (2019). Relationship management through social media influencers: Effects of followers' awareness of paid endorsement. Public Relations Review, 45(3), 101765.

Dix, S., Phau, I., \& Pougnet, S. (2010). "Bend it like Beckham": the influence of sports celebrities on young adult consumers. Young Consumers, 11(1), 36-46.

Dugalić, S., \& Lazarević, S. (2017). The impact of celebrity athlete endorsement on purchasing habits. Facta Universitatis, Series: Physical Education and Sport, 14(3), 435-446.

Düsenberg, N. B., de Almeida, V. M. C., \& de Amorim, J. G. B. (2016). The Influence of Sports Celebrity Credibility on Purchase Intention: The Moderating Effect of Gender and Consumer Sports-Involvement. BBR-Brazilian Business Review, 13, 1-21.

Fry, R., \& Parker, K. (2018). Early Benchmarks Show 'Post-Millennials' on Track to Be Most Diverse, Best-Educated Generation Yet: A Demographic Portrait of Today's 6-to 21-Year-Olds. Washington, DC: Pew Research Center.

Hameed, S. S., \& Madhavan, S. (2017). Impact of Sports Celebrities Endorsements on Consumer Behaviour of Low and High Involvement Consumer Products. XIBA Business Review (XBR), 3(1-2), 13-20.

Jungnickel, K. (2018). New Methods of Measuring Opinion Leadership: A Systematic, Interdisciplinary Literature Analysis. International Journal of Communication, 12, 2702-2724.

Kahle, L. R., \& Riley, Ch. (2004). Sports Marketing and the Psychology of Marketing Communication. New Jersey: Lawrence Erlbaum Associates, Inc.

Kapitan, S., \& Silvera, D. H. (2016). From digital media influencers to celebrity endorsers: attributions drive endorser effectiveness. Marketing Letters, 27(3), 553-567.

Khatri, P. (2006). Celebrity endorsement: A strategic promotion perspective. Indian media studies journal, 1(1), 25-37.

Koernig, S. K., \& Boyd, T. C. (2009). To Catch a Tiger or Let Him Go: The Match-up Effect and Athlete Endorsers for Sport and Non-Sport Brands. Sport Marketing Quarterly, 18(1), $25-37$. 
Koulopoulos, T., \& Keldsen, D. (2016). Gen Z Effect. The Six Forces Shaping the Future of Business. New York: Routledge.

Lee, I. (2016). Encyclopedia of e-commerce development, implementation, and management. Publisher: IGI Global.

Levine, B. (2017). What is influencer marketing? Retrieved from https://martechtoday.com /martech-landscape-influencer-marketing-194859.

Liu, L., Parganas, P., Chadwick, S., Anagnostopoulos, C., \& Parganas, P. (2016). Sports celebrity endorsements of luxury brands: the case of Chinese consumers. International Journal of Sport Management Recreation \& Tourism, 25, 45-68.

Lou, C., \& Yuan, S. (2019). Influencer marketing: how message value and credibility affect consumer trust of branded content on social media. Journal of Interactive Advertising, $19(1), 58-73$.

McCrindle, M. (2014). The ABC of XYZ: Understanding the Global Generations. Bella Vista, Australia: McCrindle Research Pty.

Novotny, P. (2017). Influencer marketing jako moderní nástroj komunikace prostřednictvím sociálních médií a návrh na jeho využití ve zvolené společnosti [Influencer marketing as a modern tool of communication through social media and a proposal for its use in the selected company. In Czech.]. Brno: Vysoke uceni technicke v Brne, Fakulta podnikatelska.

Odell, P., Wiley, D., \& Talamantez, A. (2016). 5 Influencer Marketing Trends That Are Changing the Game. Retrieved from https://www.chiefmarketer.com/5-influencermarketing -trends-that-are-changing-the-game/.

Pophal, L. (2016). Influencer marketing: turning taste makers into your best salespeople. EContent, 39(7), 18-22.

Prikrylova, J., \& Jahodova, H. (2010). Moderní marketingová komunikace [Modern Marketing Communication. In Czech.]. Praha: Grada Publishing.

Rosen, L. (2010). Welcome to the... iGeneration! The Education Digest, 75(8), 8-12.

Sammis, K., Lincoln, C., \& Pomponi, S. (2016). Influencer Marketing For Dummies. Hoboken, New Jersey: John Wiley \& Sons, Inc.

Sassenberg, A. (2015). Effects of sport celebrity transgressions: An exploratory study. Sport Marketing Quarterly, 24(2), 78-90.

Sassenberg, A. M., Summers, J., Johnson-Morgan, M., \& Hassan, R. (2018). The impact of digital communications on consumer perceptions of sport celebrity transgressions. Journal of Global Sport Management, 3(2), 189-207.

Scott, D. M. (2015). The New Rules of Marketing and PR: How to Use Social Media, Online Video, Mobile Applications, Blogs, News Releases, and Viral Marketing to Reach Buyers Directly. New Jersey: John Wiley \& Sons, Inc.

Seemiller, C., \& Grace, M. (2016). Generation Z Goes to College. San Francisco: John Wiley \& Sons, Inc.

Shuart, J. (2007). Heroes in sport: assessing celebrity endorser effectiveness. International Journal of Sports Marketing \& Sponsorship, 8(2), 126-140.

Silva, M. J. D. B., Farias, S. A. D., Grigg, M. K., \& Barbosa, M. D. L. D. A. (2020). Online engagement and the role of digital influencers in product endorsement on Instagram. Journal of Relationship Marketing, 19(2), 133-163.

Simmers, Ch. S., Damron-Martinez, D., \& Haytko, D. L. (2009). Examining the Effectiveness of Athlete Celebrity Endorser Characteristics and Product Brand Type: The Endorser Sexpertise Continuum. Journal of Sport Administration \& Supervision, 1(1), 52-64.

Sladek, S., \& Grabinger, A. (2018). Gen Z: The first generation of the 21st Century has arrived! Retrieved from https://www.xyzuniversity.com/wp-content/uploads/2018/08/GenZ Finaldl1.pdf.

Smith, A. C. T. (2008). Introduction to Sport Marketing. Oxford, UK: Elsevier. 
Stevens, J. A., Lathrop, A. H., \& Bradish, Ch. L. (2003). Who is Your Hero? Implications for Athlete Endorsement Strategies. Sport Marketing Quarterly, 12(2), 103-110.

Stillman, D., \& Stillman, J. (2017). Gen Z Work. How the Next Generation Is Transforming the Workplace. New York: Harper Business.

Torres, P., Augusto, M., \& Matos, M. (2019). Antecedents and outcomes of digital influencer endorsement: An exploratory study. Psychology \& Marketing, 36(12), 1267-1276.

Twenge, J. M. (2017). iGen: Why Today's Super-Connected Kids Are Growing Up Less Rebellious, More Tolerant, Less Happy-and Completely Unprepared for Adulthood-and What That Means for the Rest of Us. New York: Atria Books.

Voracek, J. (2015). New Perspectives of Corporate Identity in Sports Organizations. Acta Universitatis Carolinae Kinanthropologica, 50(2), 30-40.

Voracek, J. (2019). Trends and Tools in Marketing Communication in today's Sport. Marketing Identity 2019: Offline is the new online, 390-400.

Voracek, J., \& Caslavova, E. (2019). Effects of sports personalities in marketing communication on the purchasing preferences of Generation Y. Acta Universitatis Carolinae Kinanthropologica, 55(2), 107-127.

Waller, N. (2016). Beginners Guide to Influencer Marketing. Creative Review, June, 12-13.

Weinswig, D. (2016). Influencers Are The New Brands. Retrieved from https://www.forbes .com/sites/deborahweinswig/2016/10/05/influencers-are-thenew-brands/\#219b3f2e7919.

\section{APPENDIX 1}

\section{Measures of Constructs}

1. The presence of an athlete/influencer (blogger, youtuber) in the advertisement helps me to recall and recognize the product.

2. Do you think that athletes/influencers really use the promoted product in real life?

3. Do you think that the cooperation of brands with athletes/influencers is effective?

4. I get influenced to buy a product that the athlete/influencer promotes.

5. Will you be influenced by athlete's/influencer's knowledge when you decide to buy (he/she promotes what he/she understands)?

6. Will the athlete's/influencer's popularity affect you when making your purchase?

7. Have you ever purchased a product based on an advertisement from an athlete/ influencer?

8. If your favourite athlete/influencer promotes a product, will it affect you so much that you are willing to pay a higher price for that product?

9. Athletes/influencers can transfer their popularity to a product.

10. The credibility (I believe the product uses) of the athlete/influencer-product connection is important to me.

11. It makes me happy when I buy something that my favourite athlete/influencer promotes.

12. Negative publicity of an athlete/influencer can influence your purchasing decision.

13. Is it important for you that the athlete/influencer indicates advertise in his/her social media posts?

14. Can you recall a brand that a well-known athlete/influencer works with?

15. Write your favourite athletes/influencers that you follow on social networks (Instagram, Facebook, YouTube).

16. When presenting a product, I have more confidence in: Athlete 12345 Influencer. 
17. I would rather buy a product that promotes my favourite: Athlete 12345 Influencer.

18. Advertising is more convincing to me from: Athlete 12345 Influencer. 